Journal of Physical Science, Vol. 28(1), 1-13, 2017

\title{
Influence of ZnO on Physical, Mechanical and Dielectric Properties of Ceramic Bodies
}

\author{
Aisha Ezzeldin Reda, ${ }^{1}$ Doaa Abdel Naby Abdel Aziz ${ }^{1}$ and \\ Ragab Mohamed Mahani ${ }^{*}$ \\ ${ }^{1}$ Ceramic Department, National Research Centre, \\ 33 EL Bohouth St., Giza, P.O. 12622, Egypt \\ ${ }^{2}$ Microwave Physics and Dielectrics Deptartment, \\ National Research Centre, 33 EL Bohouth St., Giza, P. O. 12622, Egypt \\ *Corresponding author: rmsoliman66@yahoo.com
}

Published online: 15 April 2017

To cite this article: Reda, A. E., Abdel Aziz, D. A. N. \& Mahani, R. M. (2017). Influence of $\mathrm{ZnO}$ on physical, mechanical and dielectric properties of ceramic bodies. J. Phys. Sci., 28(1), 1-13, https://doi.org/10.21315/jps2017.28.1.1

To link to this article: https://doi.org/10.21315/jps2017.28.1.1

\begin{abstract}
Physical, mechanical and dielectric properties of ceramic bodies produced from the low-cost Egyptian raw materials with and without incorporation of $\mathrm{ZnO}$ were examined before and after annealing at different temperatures for different annealing times. The development of the crystalline phases was evaluated with $x$-ray diffraction (XRD). The dielectric properties in terms of the permittivity, dielectric loss and resistivity were investigated in the frequency range $\left(10^{-1}-10^{6} \mathrm{~Hz}\right)$ at room temperature. It was found that annealing negatively affected the physical and mechanical properties of samples. But these properties showed improvements before annealing. On the other hand, the permittivity increased with the increase of $\mathrm{ZnO}$ contents, annealing temperature and annealing time. For instance, the non-annealed samples with $5 \mathrm{wt} . \% \mathrm{ZnO}$ showed a decrease in the amount of water absorption, an increase in the modulus of rupture from 66 to $74.69 \mathrm{~N} \mathrm{~mm}^{-2}$ and improvements of the dielectric properties. Such samples may be suitable for manufacturing the electrical ceramic capacitors.
\end{abstract}

Keywords: Ceramic bodies, gahnite phase, modulus of rupture, dielectric properties, influence of $\mathrm{ZnO}$ 


\section{INTRODUCTION}

Electrical ceramic bodies have been widely used in transportation and distribution of electricity due to their useful electrical insulating properties. They have been used in insulating electrical lines from the support structure. Further, they have good mechanical properties which could be retained for more than 30 years. ${ }^{1}$ To manufacture such materials, firing processes are usually applied at temperatures higher than $1300^{\circ} \mathrm{C}$. Usually, the ceramic sintering temperature is reduced by using different flux-forming additives. In this study, natural alkali alumino-silicates (feldspar, pegmatite, perlite, nepheline syenite, etc.) or carbonates of alkali-earth metals are used. For instance, zinc oxide $(\mathrm{ZnO})$ has been used as a strong coflux in whiteware production. $\mathrm{ZnO}$ is one of the major components in commercial glazes for sanitary ware and tiles. ${ }^{2-4}$ Adding it to ceramic bodies even at small proportions results in development of zinc aluminates (gahnite phase, $\mathrm{ZnAl}_{2} \mathrm{O}_{4}$ ) which is a member of the spinel family used as a catalyst, glazing layers for floor tiles and dental applications. ${ }^{5}$

Several properties of $\mathrm{ZnAl}_{2} \mathrm{O}_{4}$ have been studied using different computational methods: cation distribution, ${ }^{6,7}$ structure, ${ }^{8,9}$ vibrational spectra, ${ }^{8}$ electronic structure, ${ }^{10}$ mechanical properties ${ }^{9,11}$ and phonon spectra..$^{11}$ In our previous work, the electrical resistivity was found to be increased to $4.4 \times 10^{12} \mathrm{Ohm}$ upon adding $4 \mathrm{wt} . \% \mathrm{ZnO}$ to the aluminous bodies. ${ }^{12,13} \mathrm{In}$ this paper, the physical and dielectric properties of ceramic bodies prepared from the Egyptian raw materials with and without adding $\mathrm{ZnO}$ were investigated. The dielectric measurements were examined by means of dielectric spectroscopy in the frequency range $\left(10^{-1}-10^{6}\right.$ $\mathrm{Hz}$ ) at room temperature.

\section{EXPERIMENTAL}

The starting Egyptian raw materials were beneficiated Tieh clay (Sinai), Abou Seberia clays near Aswan, nepheline concentrate (product of the beneficiation process of nepheline syenite rock from Abou Krug area in the Eastern Desert) and alumina $\left(\alpha-\mathrm{Al}_{2} \mathrm{O}_{3}\right)$. Their chemical compositions are listed in Table 1. $\mathrm{ZnO}$, which was obtained chemically from the pure $\mathrm{ZnCO}_{3}$, was added to the batches as 0,3 , and 5 wt.\% as listed in Table 2. Three different mixtures were produced. Each mixture was ball-milled for $2 \mathrm{~h}$ in porcelain jar with a purified water medium, then passed through a 200 mesh sieve and dried in an oven at $110^{\circ} \mathrm{C}$ for $24 \mathrm{~h}$. 
Table 1: Chemical analysis and the calculated mineralogical compositions of the raw materials in wt.\%.

\begin{tabular}{lcccc}
\hline \multirow{2}{*}{$\begin{array}{l}\text { Oxide } \\
\text { constitution }\end{array}$} & $\begin{array}{c}\text { Alumina } \\
(\alpha-\mathrm{Al} 2 \mathrm{O} 3)\end{array}$ & $\begin{array}{c}\text { Tieh } \\
\text { clay }\end{array}$ & $\begin{array}{c}\text { Abou Seberia } \\
\text { clay }\end{array}$ & $\begin{array}{c}\text { Nepheline } \\
\text { concentrate }\end{array}$ \\
\cline { 2 - 5 } $\mathrm{SiO}_{2}$ & 0.12 & 47.27 & 67.67 & 60.02 \\
$\mathrm{Al}_{2} \mathrm{O}_{3}$ & 99.50 & 35.98 & 20.95 & 23.01 \\
$\mathrm{Fe}_{2} \mathrm{O}_{3}$ & - & 0.60 & 1.40 & 0.46 \\
$\mathrm{TiO}_{2}$ & - & 2.62 & 2.00 & 0.01 \\
$\mathrm{CaO}$ & - & 0.07 & 0.08 & 0.27 \\
$\mathrm{MgO}$ & - & 0.15 & 0.14 & 0.01 \\
$\mathrm{~K}_{2} \mathrm{O}$ & - & 0.06 & 0.28 & 6.32 \\
$\mathrm{Na}_{2} \mathrm{O}$ & 0.10 & 0.039 & - & 9.69 \\
$\mathrm{P}_{2} \mathrm{O}_{5}$ & - & 0.31 & 0.03 & - \\
L.O.I & 0.26 & 13.72 & 7.98 & 1.09 \\
Total & 99.98 & 100.80 & 100.53 & 100.88 \\
\hline
\end{tabular}

Table 2: Patch compositions of the ceramic bodies.

\begin{tabular}{lccccc}
\hline \multirow{2}{*}{ Samples } & \multicolumn{5}{c}{ Patch compositions (wt.\%) } \\
\cline { 2 - 6 } & $\begin{array}{c}\text { Tieh } \\
\text { clay }\end{array}$ & $\begin{array}{c}\text { Abou Seberia } \\
\text { clay }\end{array}$ & $\begin{array}{c}\text { Alumina } \\
\left(\alpha-\mathrm{Al}_{2} \mathrm{O}_{3}\right)\end{array}$ & $\begin{array}{c}\text { Nephelin } \\
\text { concentrate }\end{array}$ & $\mathrm{ZnO}$ \\
\hline ZN0 & 40 & 30 & 20 & 10 & 0 \\
ZN3 & 40 & 30 & 20 & 10 & 3 \\
ZN5 & 40 & 30 & 20 & 10 & 5 \\
\hline
\end{tabular}

For the dielectric measurements, the dried powders were compacted and pressed (under pressure of $40 \mathrm{MPa}$ ) into discs with $1 \mathrm{~cm}$ in diameter and $0.3 \mathrm{~cm}$ in thickness. The specimens were dried at $110^{\circ} \mathrm{C}$ and then fired between $1150^{\circ} \mathrm{C}$ and $1300^{\circ} \mathrm{C}$. The firing schedule comprised heating; soaking at maximum temperature for $1 \mathrm{~h}$ and cooling to room temperature in $2 \mathrm{~h}$. Three batches were produced and denoted in the text as $\mathrm{ZN} 0, \mathrm{ZN} 3$ and $\mathrm{ZN} 5$. Another firing regime was used to anneal the specimens at $1,175^{\circ} \mathrm{C}$ and $1,200^{\circ} \mathrm{C}$ and cooling to room temperature in the furnace with two soaking times: 2 and $4 \mathrm{~h}$. Additional two batches were also produced and denoted in the text as ZNA3 and ZNA5, where A reveals to the samples after annealing.

The dielectric measurements were carried out by means of high-resolution impedance analyser spectrometer (Schlumberger Solartron 1260) provided with 
an electrometer amplifier and measuring cell to measure the dielectric properties. The output parameters are the capacitance $C(\omega)$ and the resistance $R(\omega)$, where $\omega$ is the angular frequency. The complex dielectric permittivity $\varepsilon^{*}(\omega)$ was calculated in terms of the two parameters as follows:

$$
\varepsilon^{*}(\omega)=\varepsilon^{\prime}-i \varepsilon^{\prime \prime}=\frac{C(\omega) d}{\varepsilon_{0} A}-i \frac{d}{\omega R(\omega) \varepsilon_{0} A}
$$

where $\varepsilon^{\prime}$ and $\varepsilon^{\prime \prime}$ are the real (permittivity) and imaginary part (dielectric loss) of the complex dielectric permittivity. The sample thickness is $d$, the cross sectional area is $A$, the angular frequency is $v=2 \pi \mathrm{f}$. The vacuum permittivity is $\varepsilon_{0}=8.85$ $\times 10^{-12} \mathrm{~F} / \mathrm{m}$. Electrical resistivity $(\rho)$ can be calculated as a function of $\omega$ and $\varepsilon^{\prime \prime}$ as follows:

$$
\rho=\frac{1}{\omega \varepsilon_{o} \varepsilon^{\prime \prime}}
$$

For the physical measurements, the bulk density and water absorption were determined using the Archimedes method. The measurements were carried on the ceramic bodies with the same dimensions and conditions mentioned above. For the mechanical measurements, bars with dimension $(1 \times 1 \times 7 \mathrm{~cm})$ were also processed under the same conditions and fired at selected maturing temperatures to measure the modulus of rupture (MOR) by three point method using an Instron Machine type 1128 Universal Testing.

For the crystallographic studies, the crystalline phases developed in the specimens were identified via $\mathrm{X}$-ray diffractometry (XRD) with $\mathrm{CuK} \alpha$ target while their contents were quantified by measuring the area of the strongest diffraction peak of each phase: $d_{113}$ (alumina), $d_{111}$ (cristobalite) and $d_{311}$ (gahnite). For the microstructure studies, the specimens were examined using Phlips SEM (model XL30), attached with an EDX unit for microanalysis. Specimens were mechanically polished, chemically etched by $20 \%$ hydrofluoric acid solution for $30 \mathrm{~s}$, thoroughly washed, dried and gold sputtered.

\section{RESULTS AND DISCUSSION}

\subsection{X-ray Diffraction Analyses}

Figure 1 shows $x$-ray diffraction patterns of the ceramic bodies. The main crystalline phases and their intensities are listed in Table 3. They are alumina, mullite, cristobalite, $\mathrm{ZnAl}_{2} \mathrm{O}_{4}$ (gahnite) and unreacted quartz. It is evident that the 
intensity of these phases is greatly affected by amount of $\mathrm{ZnO}$, annealing time and maximum firing temperature.

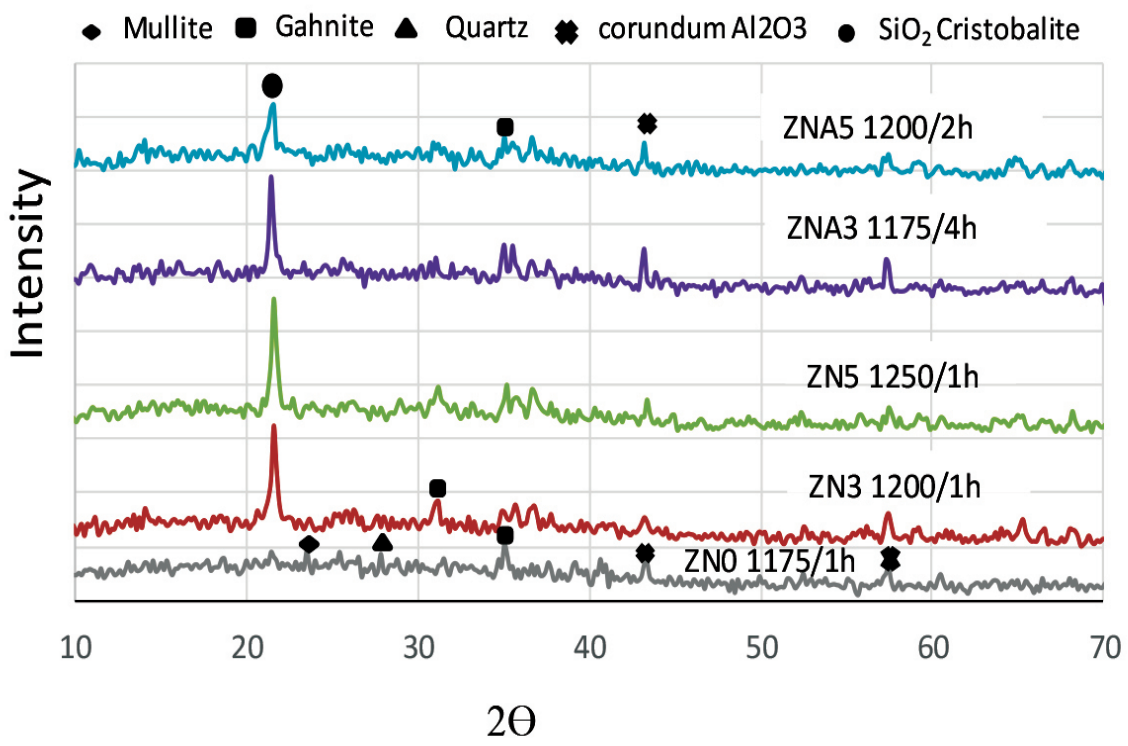

Figure 1: XRD pattern for pure ceramic bodies and $\mathrm{ZnO}$-doped bodies.

Table 3: Intensity of crystalline phases developed at pure samples and with $\mathrm{ZnO}$ addition.

\begin{tabular}{lccccc}
\hline & \multicolumn{5}{c}{ Intensity (\%) } \\
\cline { 2 - 6 } Samples & Mullite & Quartz & Cristobalite & Alumina & $\begin{array}{c}\text { Gahnite phase } \\
\left(\mathrm{ZnAl}_{2} \mathrm{O}_{4}\right)\end{array}$ \\
\cline { 2 - 6 } & 17.1 & 14.3 & $9.0(100)$ & 53.5 & - \\
\hline ZN01175/1h & 10.3 & 10.6 & $19.4(100)$ & 18.3 & 5.4 \\
ZN31200/1h & - & 10.7 & $19.2(100)$ & 18.9 & 7.6 \\
ZN51250/1h & 6.9 & 8.3 & $7.0(100)$ & 33.2 & 7.5 \\
\hline ZNA31175/4h & - & 9.7 & $7.7(100)$ & 4.1 & 24.3 \\
ZNA51200/2h & & \multicolumn{5}{c}{ After annealing } \\
\hline
\end{tabular}

Pure sample (ZN0) shows relatively higher intensity of alumina, mullite and unreacted quartz when fired at $1175^{\circ} \mathrm{C}$ for $1 \mathrm{~h}$. Upon adding $\mathrm{ZnO}$ with 3 and $5 \mathrm{wt} . \%$ $\mathrm{ZnO}$, more liquid glassy phase content developed that favoured the dissolution of primary mullite formed from clay after firing at $1200^{\circ} \mathrm{C}$ and $1250^{\circ} \mathrm{C}$ in $\mathrm{ZN} 3$ and $\mathrm{ZN} 5$, respectively. The viscosity of such glassy phase is low enough to allow 
diffusion of $\mathrm{Zn}^{2+}, \mathrm{Al}^{3+}$ and $\mathrm{Si}^{2+}$ ions that participated in crystallising $\mathrm{ZnAl}_{2} \mathrm{O}_{4}$ solid solution on cooling leaving a glass rich in silica. Similar results were reported by several authors. ${ }^{13,14}$ The annealed bodies at $1175 / 4 \mathrm{~h}$ for ZNA3 and at $1200 / 2 \mathrm{~h}$ for ZNA5 lead to small quantity of unreacted quartz due to the partially conversion of $\mathrm{SiO}_{2}$ into cristobalite.

\subsection{Morphological Analysis}

Figure 2 shows the scanning electron micrographs of the fired bodies before and after annealing. As evident from the figure, the bodies are characterised by dense but inhomogeneous crystalline microstructure containing extensively interlocking of many crystals embedded in a glassy matrix. A quartz grain seems to be under transformation from quartz to cristobalite and very small mullite crystals are observed as needle grains. Inside the glassy phase, an abundant number of fine crystals are revealed. For these bodies we observed through the EDX analyses that the fine crystals were composed of $\mathrm{ZnO}$ and $\mathrm{Al}_{2} \mathrm{O}_{3}$, the related figure is not presented in this paper. Since the gahnite is the only binary compound in $\mathrm{ZnO}$ $\mathrm{Al}_{2} \mathrm{O}_{3}$ phase diagram, ${ }^{15}$ the analysed crystal in Rosita shape must be gahnite. This in turns supports our assumption that the crystallised gahnite is formed from the feldspar melt and $\mathrm{ZnO}$ dissolution during heating to the sintering temperature. 


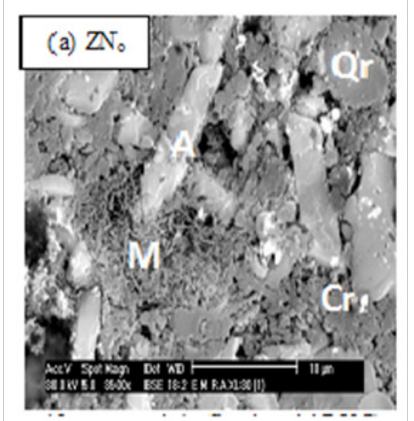

(free sample) fired at $1175^{\circ} \mathrm{C}$
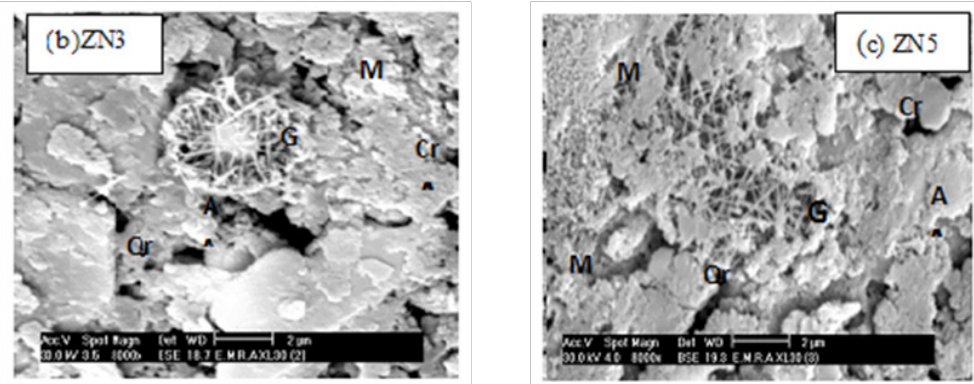

Samples before annealing at $1200^{\circ} \mathrm{C} / 1 \mathrm{~h}$ for $\mathrm{ZN} 3$ and at $1250{ }^{\circ} \mathrm{C} / 1 \mathrm{~h}$ for $\mathrm{ZN} 5$
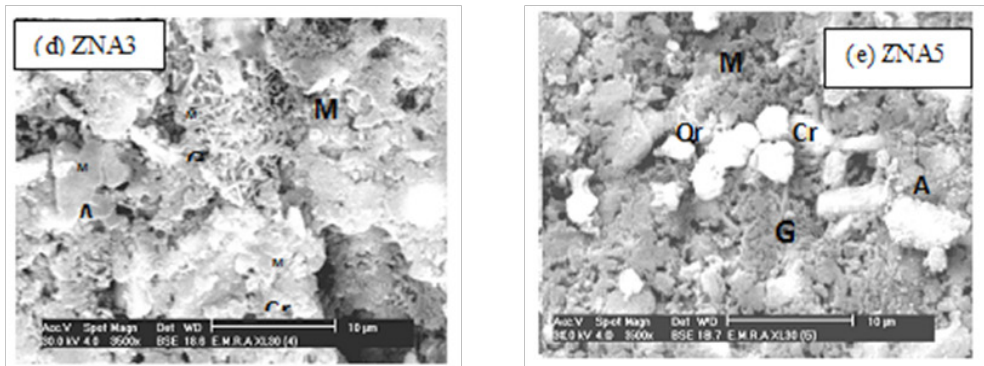

Samples after annealing at $1175^{\circ} \mathrm{C} / 4 \mathrm{~h}$ for ZNA3 and at $1250{ }^{\circ} \mathrm{C} / 2 \mathrm{~h}$ for ZNA5

Figure 2: SEM images of bodies before and after annealing $(\mathrm{Qr}=$ quartz, $\mathrm{Cr}=$ cristobalite, $\mathrm{A}=$ alumina $\left(\alpha-\mathrm{Al}_{2} \mathrm{O}_{3}\right), \mathrm{M}=$ mullite, $\mathrm{G}=$ gahnite, $\left.\mathrm{ZnAl}_{2} \mathrm{O}_{4}\right)$.

\subsection{Physical Properties}

Figure 3 shows the variation of the bulk density (BD) and water absorption (WA) with sintering temperature for free and $\mathrm{ZnO}$-ceramic bodies. The free zinc oxide bodies (ZN0) fired at $1175^{\circ} \mathrm{C}$ for $1 \mathrm{~h}$ have the bulk density values of $2.57 \mathrm{~g} \mathrm{~cm}^{-3}$ and the water absorption values of $0.74 \%$. For the bodies with 3 wt. $\% \mathrm{ZnO}(\mathrm{ZN} 3)$ and $5 \mathrm{wt} . \% \mathrm{ZnO}(\mathrm{ZN} 5)$, the maturing temperature increases from $1175^{\circ} \mathrm{C} / 1 \mathrm{~h}$ to 
$1200^{\circ} \mathrm{C}$ and from $1175^{\circ} \mathrm{C} / 1 \mathrm{~h}$ to $1250^{\circ} \mathrm{C}$, respectively. Besides, ZN3 bodies show an increase in BD up to $2.59 \mathrm{~g} \mathrm{~cm}^{-3}$ with the decrease of WA $(0.1 \%)$. For ZN5 bodies, BD shows relatively lower values $\left(2.56 \mathrm{~g} / \mathrm{cm}^{3}\right)$ and a slightly increase of WA $(0.23 \%)$ after firing for $1 \mathrm{~h}$ at $1250^{\circ} \mathrm{C}$.
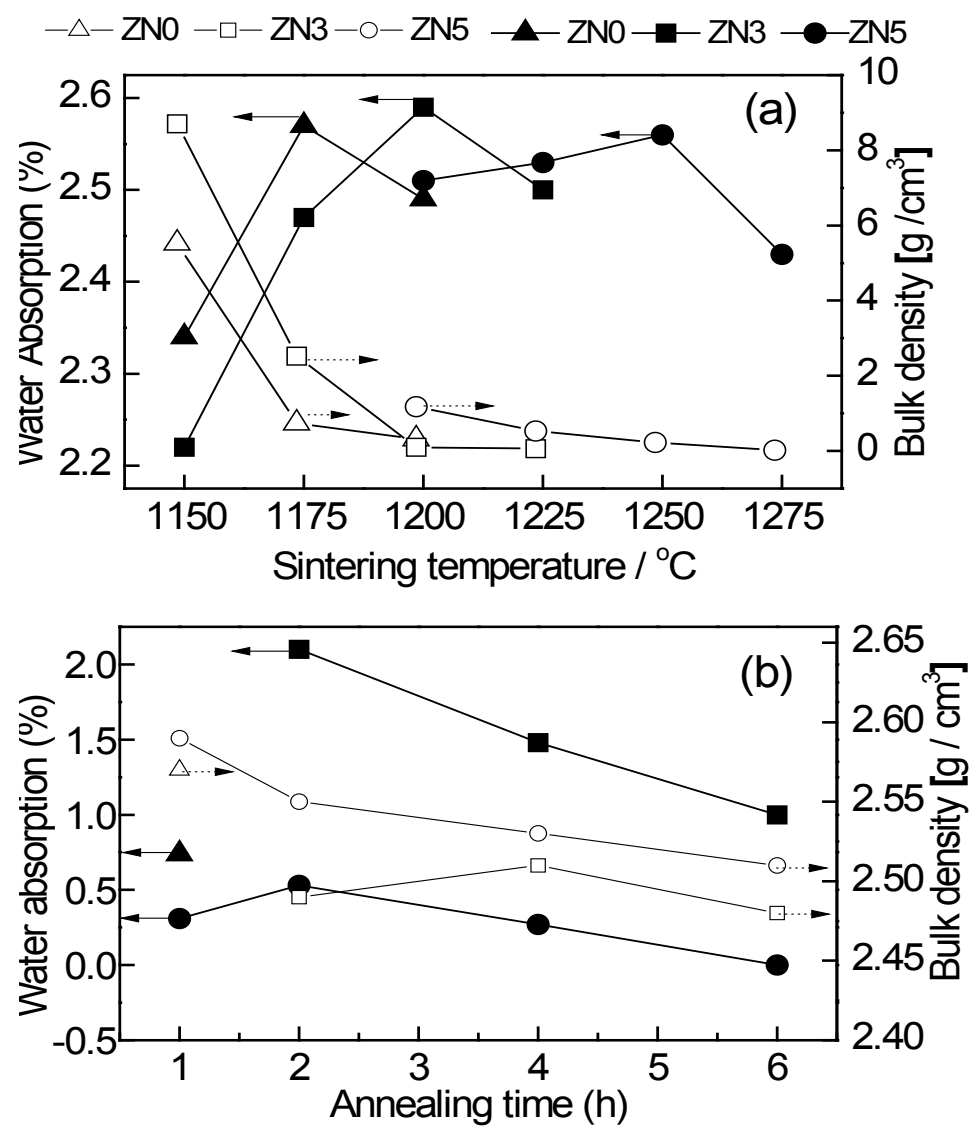

Figure 3: Water absorption and bulk density with sintering temperatures (a); and after annealing time (b) for free zinc oxide sample fired at $1175^{\circ} \mathrm{C}$ (ZN0), sample with 3 wt.\% $\mathrm{ZnO}(\mathrm{ZN} 3)$ and sample with $5 \mathrm{wt} . \% \mathrm{ZnO}$.

The effect of the second firing regime on densification in terms of BD and WA of the fired bodies is examined as listed in Table 4. It clearly shows that both ZNA3 and ZNA5 show lower bulk densities of 2.51 and $2.55 \mathrm{~g} \mathrm{~cm}^{-3}$ after annealing for 2 and $4 \mathrm{~h}$ at $1175^{\circ} \mathrm{C}$ and $1200^{\circ} \mathrm{C}$, respectively. Further, the annealing has no significant effect on the densification properties of the fired bodies in comparison with those fired without annealing. Therefore, one can conclude that the bulk density of the 
ceramic bodies are affected by $\mathrm{ZnO}$ concentration, porosity percentage and firing regime.

Table 4: Physico-mechanical properties of zinc ceramic bodies at sintered temperature (before and after annealing).

\begin{tabular}{lccc}
\hline Samples & $\begin{array}{c}\text { Bulk density } \\
\left(\mathrm{g} \mathrm{cm}^{-3}\right)\end{array}$ & $\begin{array}{c}\text { Water absorption } \\
(\%)\end{array}$ & $\begin{array}{c}\text { Modulus of rupture } \\
\left(\mathrm{N} \mathrm{mm}^{-2}\right)\end{array}$ \\
\hline ZN01175/1h & 2.57 & 0.74 & 66.00 \\
ZN31200/1h & 2.59 & 0.10 & 68.42 \\
ZN51250/1h & 2.56 & 0.23 & 74.69 \\
ZNA31175/4 h & 2.51 & 1.48 & 44.44 \\
ZNA51200/2 h & 2.55 & 0.53 & 51.17 \\
\hline
\end{tabular}

\subsection{Mechanical Properties}

Modulus of rupture (MOR) values in its dependence of firing temperature, annealing and $\mathrm{ZnO}$ content are listed in Table 4. For bodies containing 5 wt.\% of $\mathrm{ZnO}$ and before annealing (ZN5), MOR exhibits an increase and attains to the maximum values $\left(74.69 \mathrm{~N} \mathrm{~mm}^{-2}\right)$, leading to the improvements of their mechanical properties. One can attribute such improvements to the development of gahnite phase. However, after annealing, for the bodies denoted as ZNA5, MOR shows a moderate decrease from 74.69 to $51.17 \mathrm{~N} \mathrm{~mm}^{-2}$ whereas the water absorption shows a considerable increase from $0.23 \%$ to $0.53 \%$. Accordingly, the main factor that greatly affected MOR values is the variation of the crystalline phases. These observations agree with the three main theories proposed to explain the mechanical properties of porcelain ${ }^{13}$ which consider that the crystalline phases present and dispersed in the vitreous phase are the ruling factor influencing the mechanical properties.

\subsection{Dielectric Properties}

The frequency dependence of the permittivity $\left(\varepsilon^{\prime}\right)$, dielectric loss $\left(\varepsilon^{\prime \prime}\right)$ and ac resistivity $(\rho)$ of all ceramic bodies before and after annealing is shown in Figure 4. Here, both $\varepsilon^{\prime}$ and $\varepsilon^{\prime \prime}$ increase monotonically with the frequency decrease. This behaviour can be described by the Debye dispersion relations. ${ }^{16}$ The permittivity decrease is in fact associated to a decrease in the total polarisation. The total polarisations arises from the contribution of four kinds of polarisation, namely electronic, ionic, rotation or orientation, and space charge polarisation. ${ }^{17}$ The relatively high values seen in $\varepsilon^{\prime}$ at low frequencies $\left(<10^{3} \mathrm{~Hz}\right)$ are probably due to space charge polarisation. ${ }^{18-21}$ Space charge polarisation is caused by the mobile 
charges carriers which are present at the interfaces. These mobile charges are impeded by interfaces, because they are not discharged at an electrode, or because they are trapped in the material defects (vacancies, micropores, etc.).
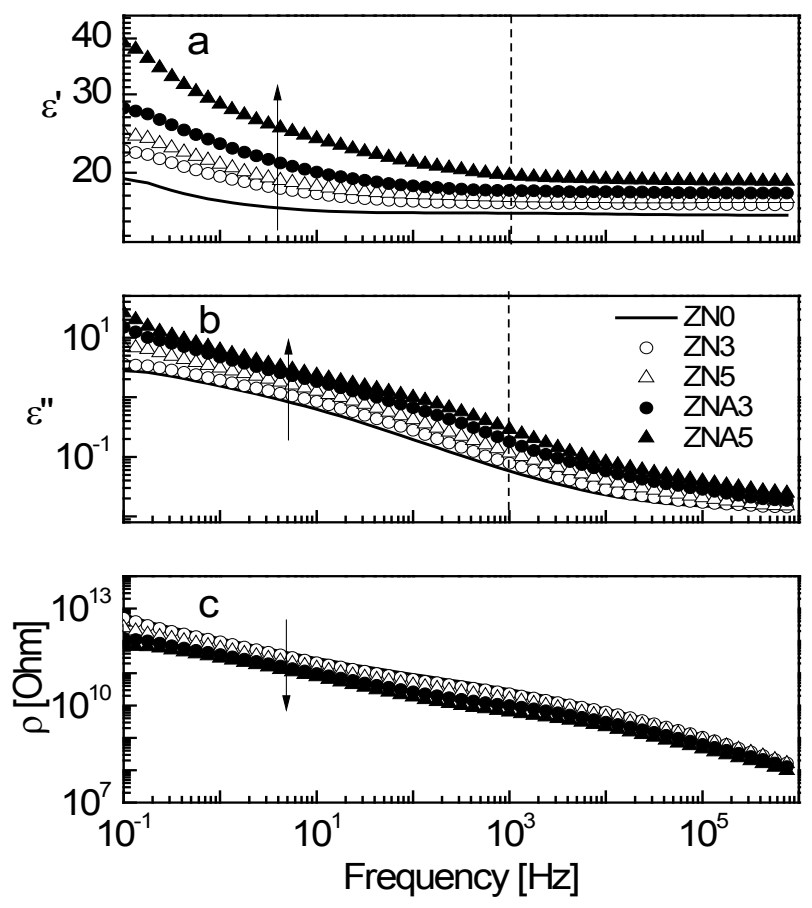

Figure 4: The frequency dependence of permittivity $\left(\varepsilon^{\prime}\right)$, dielectric loss $\left(\varepsilon^{\prime \prime}\right)$ and resistivity $(\rho)$ for ceramic bodies; free zinc oxide sample fired at $1175^{\circ} \mathrm{C}(\mathrm{ZN} 0)$, sample with $3 \mathrm{wt} . \% \mathrm{ZnO}$ before annealing (ZN3), sample with $5 \mathrm{wt} . \% \mathrm{ZnO}$ before annealing (ZN5), sample with 3 wt.\% $\mathrm{ZnO}$ after annealing at $1175^{\circ} \mathrm{C} / 4 \mathrm{~h}$ (ZNA3), and sample with $5 \mathrm{wt} . \% \mathrm{ZnO}$ after annealing at $1,250^{\circ} \mathrm{C} / 2 \mathrm{~h}$ (ZNA5).

When an external electric field is applied, the space charge moves and then becomes trapped by the ceramic defects, causing changes in the positive and negative charges distribution at the interfaces. Hence, a lot of dipole moments are formed (space charge polarisation). Therefore, the interfacial polarisation is the main factor that affects permittivity of any heterogeneous material likes ceramic materials. In the high frequency region $\left(>10^{3} \mathrm{~Hz}\right), \varepsilon^{\prime}$ shows a plateau-like behaviour indicating dipolar or orientation polarisation dependence. Here, the dipole would be unable to follow the rapid change in the electric field frequency, hence the orientation polarisation stops and $\varepsilon^{\prime}$ becomes constant. 
The orientation polarisation may occur in the ceramic bodies when two or more equivalent positions for an ion are present. Upon applying an electric field, ions such as $\mathrm{Zn}^{2+}, \mathrm{Al}^{3+}$ and $\mathrm{Si}^{2+}$ can be exchanged in positions with the possible vacancies by a simple jump of the cation to the nearest vacancy. Therefore, orientation polarisation is also known as ion jump polarisation. On the other hand, the ceramic dielectric loss $\left(\varepsilon^{\prime \prime}\right)$ shows a decrease at two different rates indicating two different relaxation processes. Further, the relatively high values seen in $\varepsilon^{\prime \prime}$ at low frequencies could be related to contribution of DC conductivity (reciprocal of resistivity).

The ceramic permittivity values can also be correlated with $\mathrm{ZnO}$ contents and annealing temperature. For instance, sample with the higher contents of $\mathrm{ZnO}$ and annealed at $1200^{\circ} \mathrm{C} / 2 \mathrm{~h}$ (ZNA5) exhibits the maximum permittivity (40 at $\mathrm{v}$ $=0.1 \mathrm{~Hz}$ ). This is probably attributed to the mobility increase of dipoles or/and charge carriers due to the development of more liquid phase content upon adding $\mathrm{ZnO}$ as mentioned above. This leads to a decrease in the ceramic resistivity as shown in Figure 4(c). Therefore, the substitution of $\mathrm{Zn}^{2+}$ leads to an increase in the conduction ions density and hence lowering the ceramic resistivity. For such a case, the metal oxides or mineralisers become dissolved partially into the glassy phase causing a resistivity decrease.

\section{CONCLUSION}

Physical, mechanical and dielectric properties of the ceramic bodies containing zinc oxide and firing at high temperatures between $1150^{\circ} \mathrm{C}$ and $1300^{\circ} \mathrm{C}$ were improved due to developments of the gahnite phase $\left(\mathrm{ZnAl}_{2} \mathrm{O}_{4}\right)$. For instance, the ceramic bodies with $5 \mathrm{wt} . \% \mathrm{ZnO}$ fired at $1250^{\circ} \mathrm{C}$ for $1 \mathrm{~h}$ were characterised by the maximum modulus of rupture $\left(74.69 \mathrm{~N} \mathrm{~mm}^{-2}\right)$, high permittivity $(\sim 20)$ and a continuous decrease in dielectric loss. These features revealed to the possibility of use such bodies as electrical capacitors or as a good replacement of $\mathrm{SiO}_{2}$ in high power devices. The interesting features given for such ceramics may make them technologically important and competitive to other alternative electronic devices, not only due to the low cost but also due to easy processing and the availability of raw materials.

\section{ACKNOWLEDGEMENTS}

The authors would like to thank National Research Centre (NRC), Cairo, Egypt for financial support under grants P101008. 


\section{REFERENCES}

1. Ramaswamy P., Vyatheya S. \& Seetharamu S. (2005). Significance of structure-property relationship in alumina based porcelain insulators to achieve quality. Bull. Mater. Sci., 28(7), 681-688, https://doi.org/10.1007/ BF02708538.

2. Eppler R. A. \& Eppler D. R. (2000). Glazes and glass coatings. Ohio: The American Ceramic Society.

3. Parmelee C. W. (1973). Ceramic glazes, 3rd ed. Massachusetts: CBI Publishing.

4. Taylor J. R. \& Bull A. C. (1986). Ceramic glaze technology, 3rd ed. Oxford: Pergamon Press.

5. Navrotsky, A. \& Kleppa, O. J. (1967). The thermodynamic of cation distributions in simple spinels. J. Inorg. Nucl. Chem., 29, 2701-2714, https:// doi.org/10.1016/0022-1902(67)80008-3.

6. Cormack, A. N. et al. (1988). On the cation distribution in spinels. J. Phys. Chem. Solids, 49, 53-57, https://doi.org/10.1016/0022-3697(88)90134-5.

7. Grimes R. W., Anderson A. B. \& Heuer A. H. (1989). Predictions of cation distributions in $\mathrm{AB}_{2} \mathrm{O}_{4}$ spinels from normalized ion energies. J. Am. Chem. Soc., 111, 1-7, https://doi.org/10.1021/ja00183a001.

8. Alvarez, L. J., Bosch P. \& Valenzuela, M. A. (1993). Molecular dynamics studies of $\mathrm{ZnAL}_{2} \mathrm{O}_{4}$ spinel. Catal. Lett., 22(4), 361, https://doi.org/10.1007/ BF00807245.

9. Pandey, R. et al. (1999). Atomistic simulation study of spinel oxides: Zinc aluminate and zinc gallate. J. Am. Ceram. Soc., 82(12), 3337-3341, https:// doi.org/10.1111/j.1151-2916.1999.tb02248.x.

10. Sampath S. K., Kanhere D. G. \& Pandey, R. (1999). Electronic structure of spinel oxides: Zinc aluminate and zinc gallate. J. Phys. Condens. Matter, 11(18), 3635-3644, https://doi.org/10.1088/0953-8984/11/18/301.

11. Fang, C. M. et al. (2002). Phonon spectrum of $\mathrm{ZnAl} 2 \mathrm{O} 4$ spinel from inelastic neutron scattering and first-principles calculations J. Phys. Rev. B, 66, 144301, https://doi.org/10.1103/PhysRevB.66.144301.

12. Sallam E. H. et al. (2001). Influence of $\mathrm{Zn}^{2+}$ ion addition on properties of aluminous electrical porcelain. Brit. Ceram. Trans., 100(4), 177-180, http:// dx.doi.org/10.1179/096797801681422.

13. Abdel Aziz, D. A. et al. (2010). Physico-electrical properties of ceramic bodies based on nepheline tailing and clay. Ind. Ceram., 30(2), 89-95.

14. Lee, S. M. et al. (2005). Crystallization behavior and mechanical properties of porcelain bodies containing zinc oxide additions. J. Eur. Ceram. Soc., 25(11), 1829-1834, https://doi.org/10.1016/j.jeurceramsoc.2004.06.009. 
15. Hunting, E. N. et al. (1964). In-phase diagrams for ceramists. Ohio: The American Ceramic Society.

16. Nora, E. H. (1969). Dielectric properties and molecular behavior. London: Van Nostrand.

17. Kingery, W. D. (1976). Introduction to ceramics. New York: John Wiley and Sons.

18. Carty W. M. \& Senapati, U. (1998). Porcelain: Raw materials, processing, phase evolution, and mechanical behavior. J. Am. Ceram. Soc., 81(1), 3-20, https://doi.org/10.1111/j.1151-2916.1998.tb02290.x.

19. Macdonald, J. R. (1953). Theory of AC space-charge polarization effects in photoconductors, semiconductors and electrolytes. Phys. Rev., 92(1), https:// doi.org/10.1103/PhysRev.92.4.

20. James, C. M. (2010). Treatise on electricity and magnetism. London: Oxford University Press.

21. Wagner, K. W. (1914). Explanation of electric relaxation processes based on Maxwell's ideas. Arch. Electr., 2(9), 371-387, https://doi.org/10.1007/ BF01657322. 